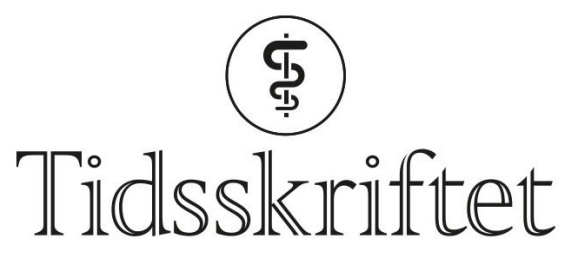

DEN NORSKE LEGEFORENING

\title{
Hvordan påvirker trening hjernen?
}

FRA ANDRE TIDSSKRIFTER

KARI TVEITO

Tidsskriftet

Melkesyre fra muskelarbeid øker vekstfaktormengde og kapillærtetthet i hjernen. Det viser en norsk musestudie.
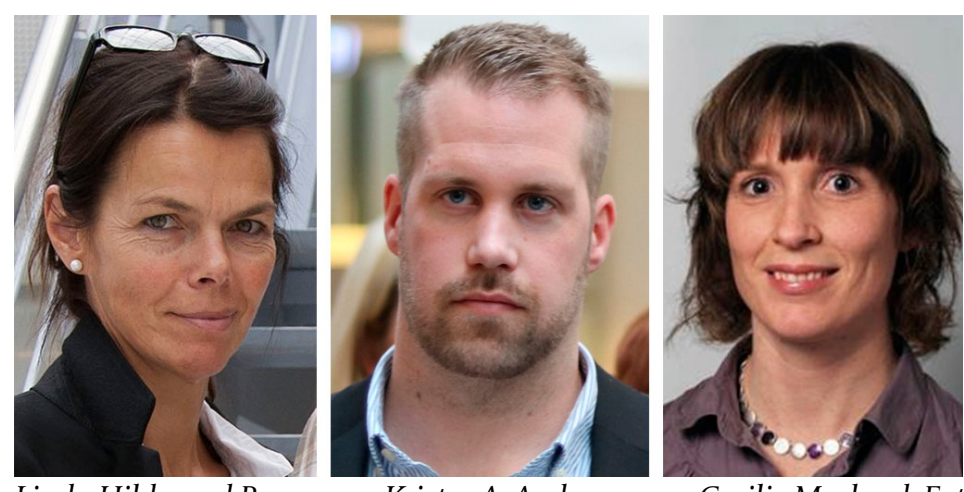

Linda Hildegard Bergersen, Krister A. Andersson og Cecilie Morland. Foto: Universitetet i Oslo

Fysisk aktivitet er vist å bedre hjernefunksjonen og å motvirke sykdoms- og aldersforandringer i hjernen, men signalveiene som fører til dette, er ukjente. Forskere ved Universitetet i Oslo har nylig vist at laktat, som produseres i store mengder under intens muskelaktivitet, har en gunstig påvirkning på hjernen (1). 


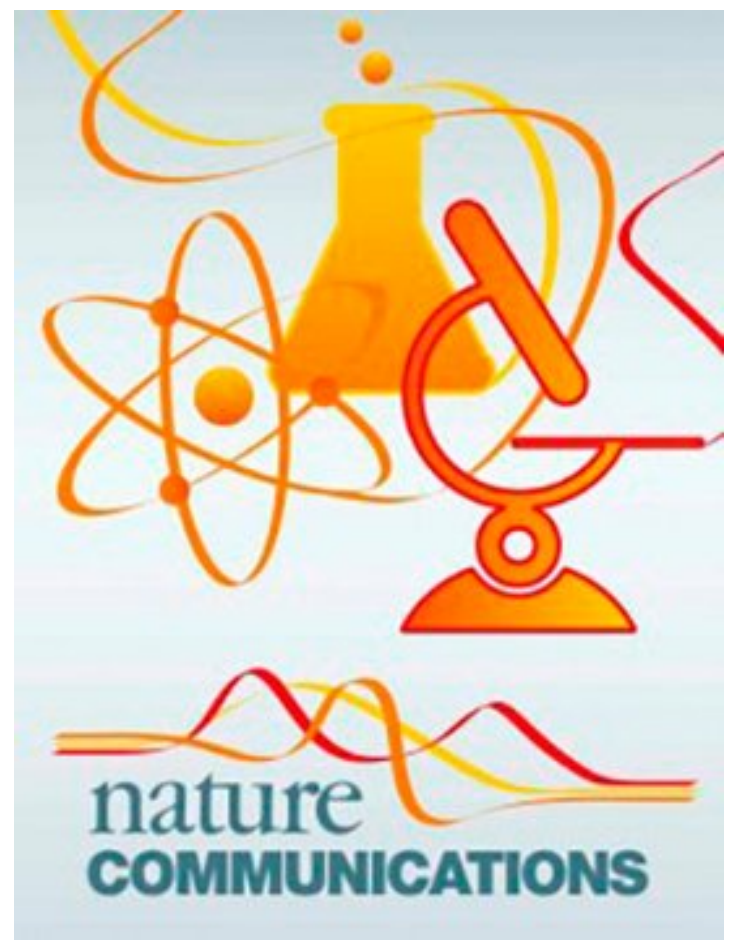

Artikkelen ble publisert i Nature Communications 23. mai 2017

I studien ble det påvist økte mengder av en vekstfaktor (vascular endothelial growth factor A, VEGFA) i hippocampus og $ø$ kt tetthet av blodkapillærer i hippocampus og somatosensorisk cortex hos mus etter intens intervalltrening fem dager i uken i syv uker. Disse virkningene ble reprodusert ved å injisere laktat subkutant fem dager i uken i syv uker, i mengder som ga blodlaktatnivå på omtrent samme nivå som ved intervalltreningen. Hos mus uten laktatreseptoren HCAR1 ga verken trening eller laktatinjeksjon endring i vekstfaktormengden eller i kapillærtettheten.

- Forstyrret mikrosirkulasjon i hjernen bidrar til forandringene ved Alzheimers sykdom og andre former for demens, forklarer Linda Hildegard Bergersen, som er professor ved Universitetet i Oslo og sisteforfatter i studien . - Den aktuelle vekstfaktoren er tidligere vist å kunne stimulere vekst av kapillærer i hjernen og å gjøre synapsene mer effektive, slik at nervecellene "lærer" raskere.

- Glykolysen og derved laktatproduksjonen øker umiddelbart når nerveceller blir aktivert. Hjernen kan også ta opp og forbrenne laktat fra blodet når musklene er aktive. HCAR1reseptoren blir aktivert i begge tilfeller. Det er viktig å finne ut mer om signalveiene som aktiveres via HCAR1-reseptoren, og om HCAR1-reseptoren kan utnyttes i forebygging og behandling av sykdom. Fysisk aktivitet er nødvendig og har åpenbart mange gunstige virkninger på kroppen, også uavhengig av HCAR1-reseptoren, men en «HCAR1treningspille» vil kunne være nyttig for personer som ikke er i stand til å utføre så intens fysisk aktivitet at HCAR1-reseptoren blir aktivert fullt ut.

- De positive endringene som ble observert, var forårsaket av intermitterende økning i laktat. Kronisk økt blodlaktat er derimot forbundet med en rekke patologiske tilstander, blant annet Alzheimers sykdom, kreft og kronisk utmattelsessyndrom. Tidligere studier har vist at vedvarende høyt laktatnivå fører til at HCAR1-reseptoren trekkes inn i cellen slik at den ikke kan reagere som før. Dette er et viktig moment å ha klart for seg hvis man skal forsøke å utvikle en «treningspille», sier Bergersen.

\section{Forskningsgruppen}

Arbeidet er utført av Brain and Muscle Energy Group ved Institutt for oral biologi og Institutt for medisinske basalfag, Universitetet i Oslo, som ledes av professor Linda Hildegard Bergersen. Gruppen har samarbeidspartnere ved Oslo universitetssykehus, i Trondheim og i Tyskland. 
Artikkelens to førsteforfattere, Cecilie Morland og Krister A. Andersson, var henholdsvis postdoktorstipendiat og doktorgradsstipendiat i gruppen da studien ble utført. Cecilie Morland er nå førsteamanuensis ved Farmasøytisk institutt, Universitetet i Oslo, og ved Høgskolen i Oslo og Akershus. Artikkelen springer ut av forskningsprosjektet «How does physical exercise translate into better brains?», støttet av Forskningsrådets program for fri grunnforskning.

LITTERATUR:

1. Morland C, Andersson KA, Haugen $\emptyset \mathrm{P}$ et al. Exercise induces cerebral VEGF and angiogenesis via the lactate receptor HCAR1. Nat Commun 2017; 8: 15557. [PubMed][CrossRef]

Publisert: 4. september 2017. Tidsskr Nor Legeforen. DOI: 10.4045/tidsskr.17.0538

(ㅇ) Tidsskrift for Den norske legeforening 2020. Lastet ned fra tidsskriftet.no 